\title{
Analysis Critical Success Factor for Toll Road Performance Improvement with Dynamic Model
}

\author{
Sumadiyono, and Albert Eddy Husin \\ Department Master Program of Civil Engineering \\ Mercu Buana University, Jakarta \\ Indonesia
}

\begin{abstract}
In toll road construction, all aspects need to be considered, from planning, implementing, and meeting minimum service standards during operations. In addition, to reduce the risk of toll road project investment by reducing the risk of rework. Repetitive work (rework) has a direct and indirect impact on project performance which has an impact on costs, rework is also a very significant contributor to waste or additional time which results in the completion of the project schedule. This research answers the factors related to the increase in cost and time performance. Cost-related research discusses rework modeling using the System Dynamic and time-related research using the Line of Ballance. Rework is a problem in construction that can be caused by many interrelated aspects that are not taken into account in planning. Rework modeling using a System Dynamic can provide simulations to get the best results. The research obtained 12 outcome factors that affect cost and time performance on a toll road project, a dynamic system implementation can provide optimal solutions with the ability to reduce the proportion of the number of rework by $23.11 \%$ for 42 months.
\end{abstract}

Key Words: SPSS, Rework, Cost performance, System Dynamic.

\section{INTRODUCTION}

Efficient and extensive infrastructure aims to ensure the effectiveness of the functioning of the economy. Infrastructure development is expected to increase accessibility, increase the competitiveness of a region to integrate domestic and international markets at competitive costs and on time [1]. In road works on the project, many theories can be done, from the data collected as many as 1,722 toll road projects taken from 1995 to 2001 by the Indiana Department of Transportation, the United States, which obtained $11.95 \%$ toll road delays [2]. The high investment in toll road construction and the low rate of return on interest, which is only around $7.79 \%$, makes it difficult to attract private investors to participate in the current toll road infrastructure development, which requires alternatives, ideas, implementation methods, and innovative creativity to add functions and benefits to it. Projects [3].

In toll road construction, all aspects need to be considered, from planning, implementing, and meeting minimum service standards during operations. Also, to reduce the risk of toll road project investment by reducing the risk of rework. Rework has a direct and indirect impact on project performance. This is an important factor that contributes to the costs and excess time of construction projects [4] Waste of costs in transportation infrastructure projects, such as road projects, is often caused by rework [5,6]. The cost of rework on most construction projects is large, ranging from $5 \%$ to $20 \%$ of the contract value [7,8]. Apart from having an impact on costs, rework is also a significant contributor to the time wastage and schedule delays of a project [9]. The average rework adds to the time required for project completion by $22 \%$ of the planned time [10]. Rework has also been indicated as a second cause for loss of worker productivity and is a problem that often arises in both design and construction work [11]

\section{LITERATURE STUDY}

\subsection{Rework}

Types of rework: (1) Repair, the scope of repair includes rework to return the condition of a certain work item to its original condition (the work in question is already in a finished state); (2) Revision, the scope of revision includes work done to complete or improve work items that have changed as a result of the work execution process; (3) Replacement, is a repair activity by replacing a unit of material or a work result because it does not function according to standards; and (4) Redesign, is a repair activity carried out by the designer or implementer to redesign the design. 
The level of uncertainty inherent in construction projects can be problematic, especially if the available information is incomplete, the results of which can affect decision-making during the project [12]. Due to a lack of knowledge, decisions made before or during construction may lead to mistakes that lead to rework [13].

In the toll road project, rework work may occur due to design changes caused by land changes that have not been acquired, resulting in design changes that result in changes in construction costs which result in changes in the scope of construction of the Toll Road Business Entity.

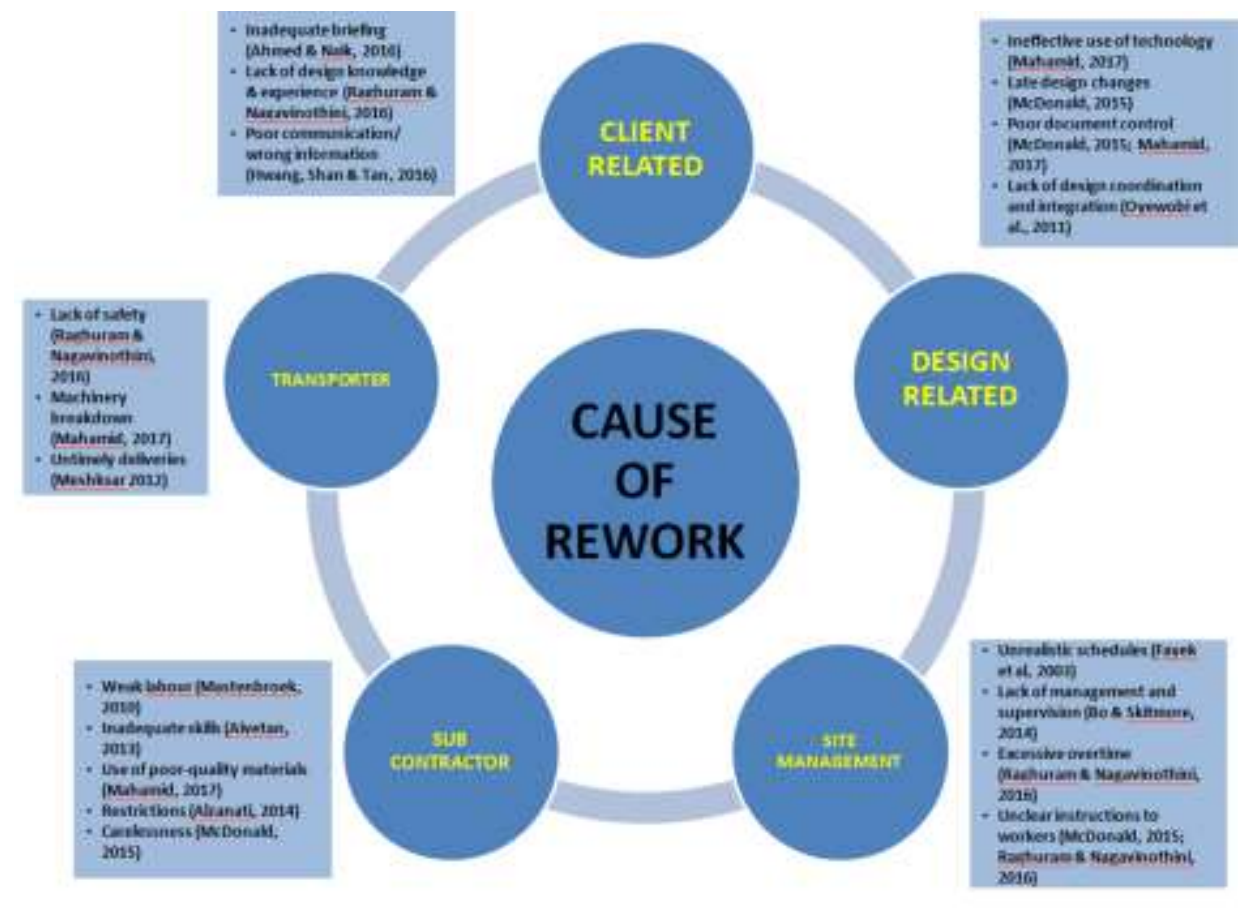

Figure 1. Factors that affect rework [14]

\subsection{SYSTEM DYNAMIC}

The stages in developing a System Dynamic model are starting from defining the problem (Problem Articulation) which will be raised by creating a System Dynamic [15]. The second stage is making an initial hypothesis (Dynamics Hypothesis) armed with the problems in the first stage. The third stage is formulation. The fourth stage is the testing phase with various combinations or policy scenarios (Testing). The fifth stage or the last stage is making the best policy from the previous stage and conducting an evaluation. The five stages are shown in (Figure 1). The advantage of a System Dynamic is that it has a feedback structure that is interrelated and leads to balance [15].

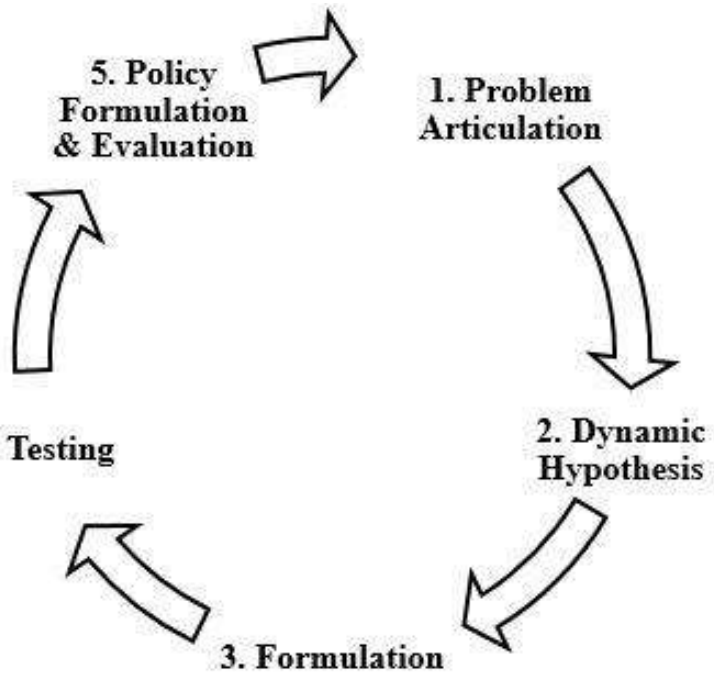

Figure.2 Process in System Dynamic modeling [15] 


\section{RESEARCH METHODOLOGY}

This study aims to improve cost and time performance on toll road projects, where the achievement of cost and time optimization. the research flow is shown in (Figure 3). To answer the research question of how the implementation of a System Dynamic can improve the cost performance of toll road projects. The following is a flowchart of System Dynamic implementation. To answer the research question of how the implementation of a Line of Balance can improve the time performance of toll road projects. The following is a flowchart of the Line of Balance implementation.

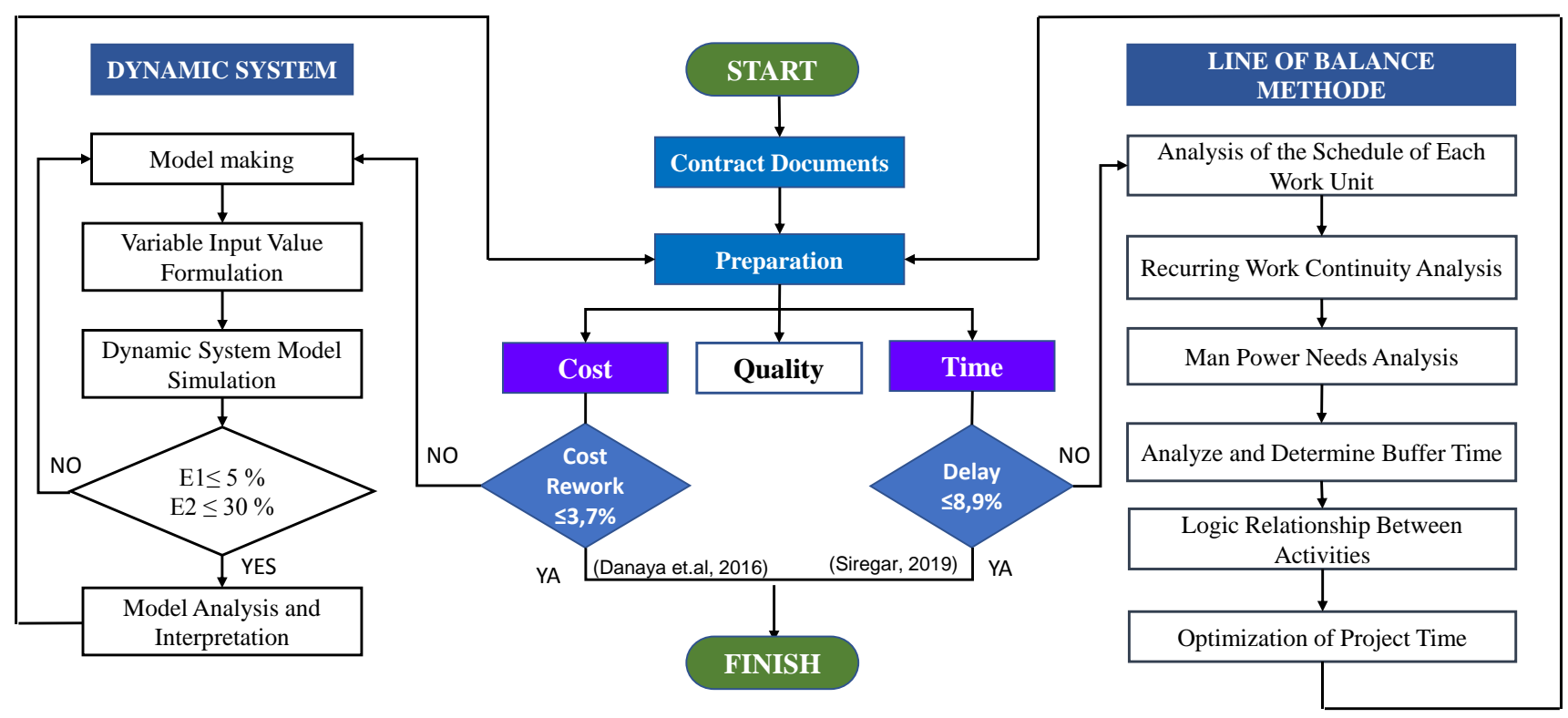

Figure.3 Flowchart implementation Case Study

\subsection{Variable Identification}

The variables in this study include:

1) Rework (independent variable)

2) Project scheduling (independent variable)

3) Factors Affecting Cost and Time Performance on Toll Road Projects (dependent variable)

The factors that influence toll road performance are obtained from literature studies and questionnaires of toll road project stakeholders and statistical analysis was performed using SPSS Factors Affecting Toll Road Project Performance

Table 1 Factors Affecting Toll Road Project Performance

\begin{tabular}{|c|l|c|}
\hline No & \multicolumn{1}{|c|}{ Weight Factor } & \% \\
\hline 1 & Design change & $9.49 \%$ \\
\hline 2 & Lack of Supervision & $9.24 \%$ \\
\hline 3 & Working Methods are not suitable & $9.05 \%$ \\
\hline 4 & Changes to specifications & $8.62 \%$ \\
\hline 5 & Contractor Negligence & $8.62 \%$ \\
\hline 6 & Plans lacking detail & $8.21 \%$ \\
\hline 7 & Material Delay & $8.02 \%$ \\
\hline 8 & Lack of knowledge PM and SM & $7.91 \%$ \\
\hline 9 & Skilled workers & $7.80 \%$ \\
\hline 10 & Equipment Selection & $7.78 \%$ \\
\hline 11 & Land Acquisition & $7.69 \%$ \\
\hline 12 & Extreme Weather & $7.57 \%$ \\
\hline
\end{tabular}




\subsection{Implementation Of Dynamic System}

In this part of the study, the implementation of dynamic systems in the Cinere Serpong toll road construction project work, to answer research question dynamic system implementation to improve cost performance on toll road projects, namely how to implement dynamic systems to improve cost performance on toll road projects.

\subsubsection{Causal Loor Diagram (Cld)}

Causal loop diagrams must be done before making a model so that the model builder has a first picture of the concept of the model to be made. The causal loop diagram as shown in Figure 4 shows the causal relationship which is connected utilizing arrows. Causal loop diagrams are useful for describing the relationship between variables involved in a system

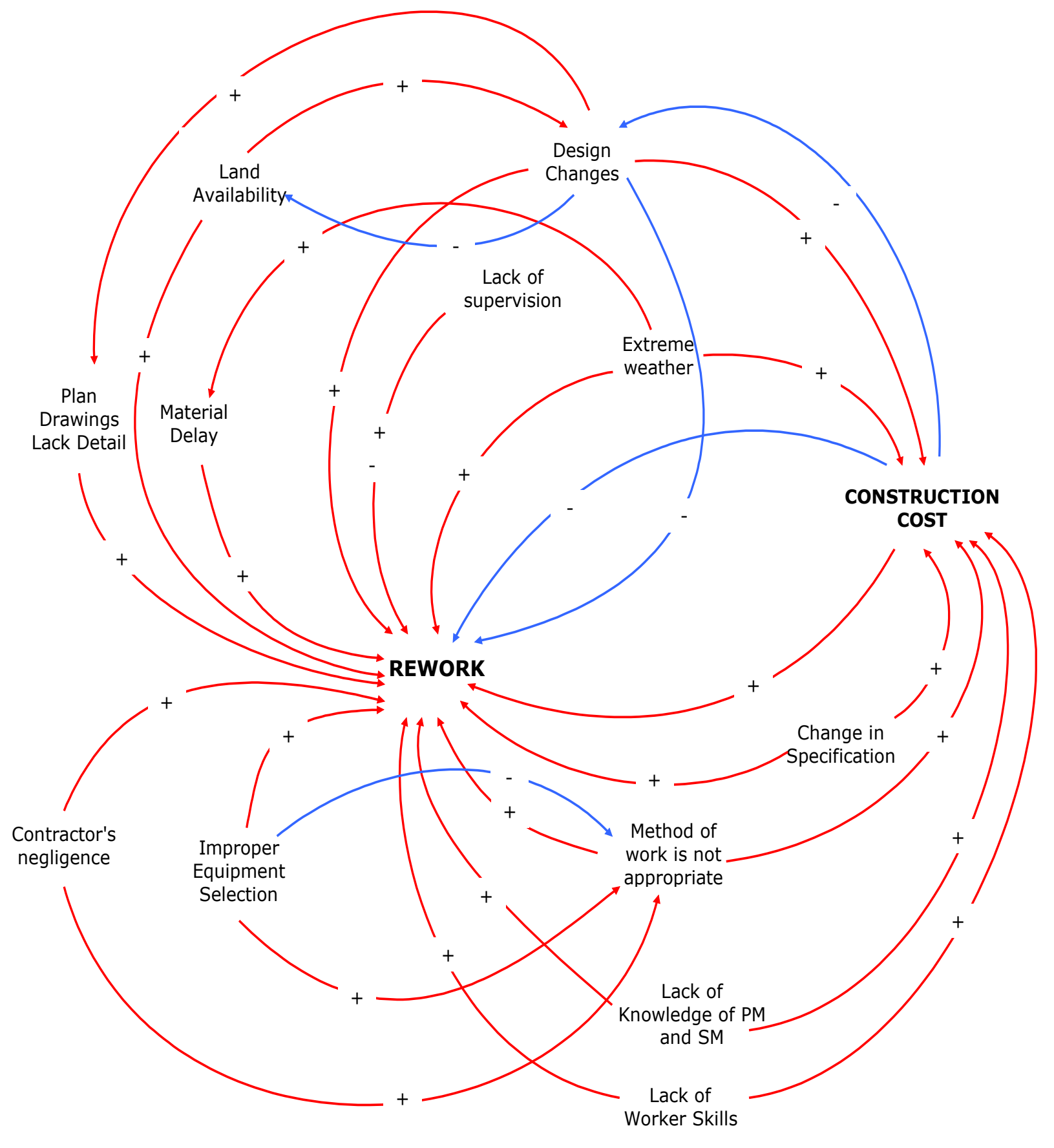

Figure 3 Causal Loop 


\subsubsection{Stok Flow Diagram (Sfd)}

Stock flow diagrams can be used to find out how to improve cost performance on toll road projects that begin during the design process made using one of the software for System Dynamic modeling, namely Powersim Studio 10 software. Figure 4 is a depiction of the initial stock-flow diagram in the model in this study

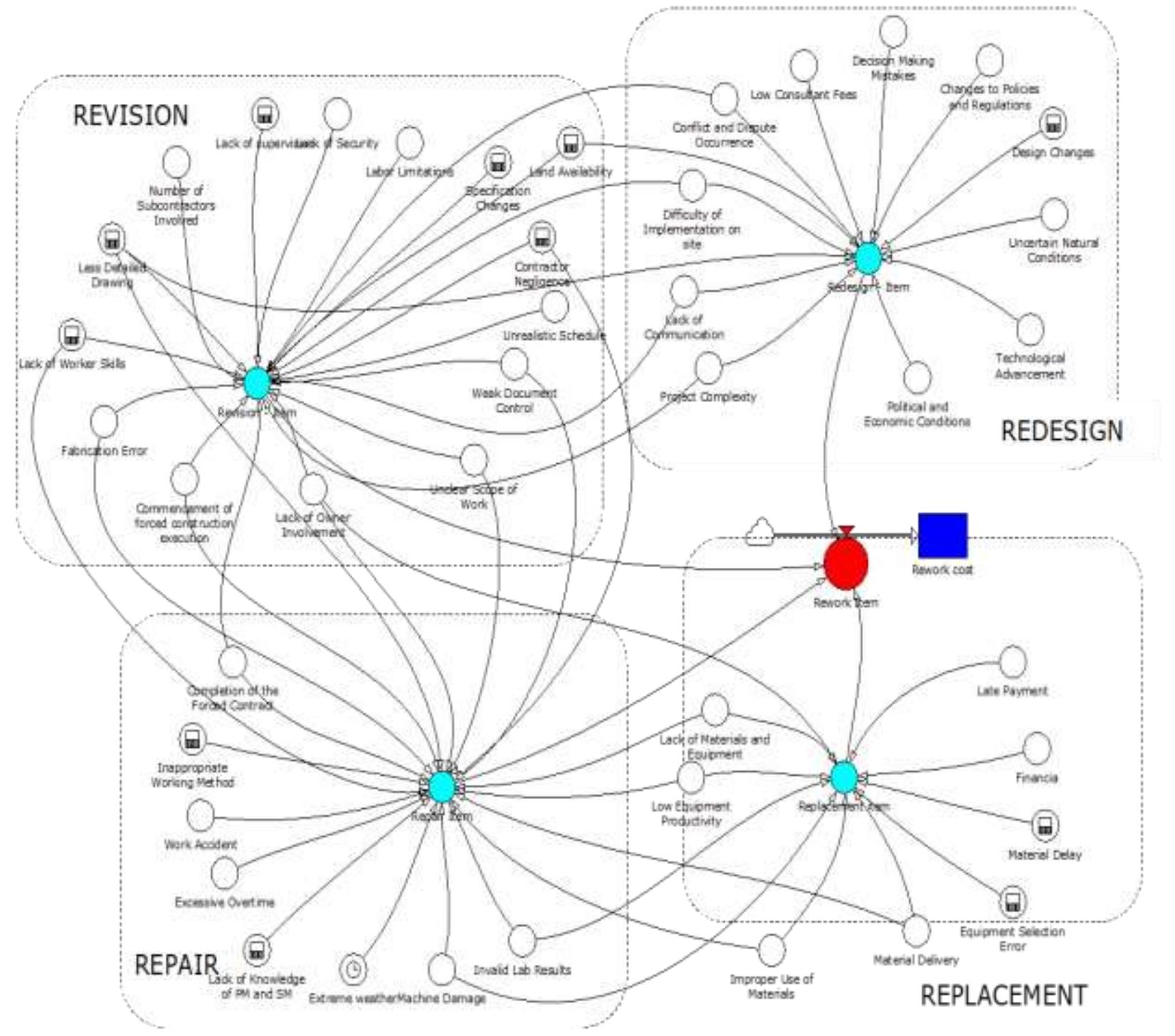

Figure 4 Stock flow Dagrams

\subsubsection{Input Value Formulation}

The input value formulation is obtained from the results of the SPSS output regarding the factors that affect the cost performance of toll road projects, then for a detailed explanation, interviews are conducted with stakeholders, BUJT, the Board of Directors Team, Planning Consultants, Supervisory Consultants and PM and SM on toll road construction projects.

\subsubsection{Model Validation}

The input value formulation is obtained from the results of the SPSS output regarding the factors that affect the cost performance of toll road projects, then for a detailed explanation, interviews are conducted with stakeholders, BUJT, the Board of Directors Team, Planning Consultants, Supervisory Consultants and PM and SM on toll road construction projects. 


\subsubsection{Scenario}

In this research, the scenario aims to reduce the percentage of the number of reworks by adding improvement scenarios and then seeing the impact of whether it can reduce the percentage of the number of reworks on toll road construction projects. The following are some of the formulations of improvement scenarios used in this study:

Table 2. Scenario

\begin{tabular}{|c|c|c|}
\hline No. & Scenario & Remarks \\
\hline 1 & Scenario 1 & (1) Increase the number of Engineers \\
\hline 2 & Scenario 2 & $\begin{array}{l}\text { (1) Increase the number of Engineers, and (2) Adding a measurement } \\
\text { corridor. }\end{array}$ \\
\hline 3 & Scenario 3 & $\begin{array}{l}\text { (1) Increase the number of Engineers; (2) Adding a measurement corridor; } \\
\text { and (3) Adding Geotechnical Investigation. }\end{array}$ \\
\hline 4 & Scenario 4 & $\begin{array}{l}\text { (1) Increase the number of Engineers; (2) Adding a measurement corridor; } \\
\text { (3) Adding Geotechnical Investigation, and (4) Increase the number of } \\
\text { supervisors. }\end{array}$ \\
\hline 5 & Scenario 5 & $\begin{array}{l}\text { (1) Increase the number of engineers; (2) Adding a measurement corridor; (3) } \\
\text { Adding Geotechnical Investigation; (4) Increase the number of supervisors; } \\
\text { and (5) Training. }\end{array}$ \\
\hline 6 & Scenario 6 & $\begin{array}{l}\text { (1) Increase the number of Engineer; (2) Adding a measurement corridor; (3) } \\
\text { Adding Geotechnical Investigation; (4) Increase the number of supervisors; } \\
\text { (5) Training; and (6) Creating a project information system }\end{array}$ \\
\hline 7 & Scenario 7 & 1. Adding a measurement corridor \\
\hline 8 & Scenario 8 & $\begin{array}{l}\text { (1) Adding a measurement corridor, and (2) Adding Geotechnical } \\
\text { Investigation }\end{array}$ \\
\hline 9 & Scenario 9 & $\begin{array}{l}\text { (1) Adding a measurement corridor; (2) Adding Geotechnical Investigation, } \\
\text { and (3) Increase the number of supervisors }\end{array}$ \\
\hline 10 & Scenario 10 & $\begin{array}{l}\text { (1) Adding a measurement corridor; (2) Adding Geotechnical Investigation; } \\
\text { (3) Increase the number of supervisors; and (4) Training. }\end{array}$ \\
\hline 11 & Scenario 11 & $\begin{array}{l}\text { (1) Adding a measurement corridor; (2) Adding Geotechnical Investigation; } \\
\text { (3) Increase the number of supervisors; (4) Training; and (5) Creating a } \\
\text { project information system }\end{array}$ \\
\hline 12 & Scenario 12 & (1) Adding Geotechnical Investigation. \\
\hline 13 & Scenario 13 & $\begin{array}{l}\text { (1) Adding Geotechnical Investigation, and (2) Increase the number of } \\
\text { supervisors }\end{array}$ \\
\hline 14 & Scenario 14 & $\begin{array}{l}\text { (1) Adding Geotechnical Investigation; (2) Increase the number of } \\
\text { supervisors; and (3) Training. }\end{array}$ \\
\hline 15 & Scenario 15 & $\begin{array}{l}\text { (1) Adding Geotechnical Investigation; (2) Increase the number of } \\
\text { supervisors; (3) Training; and (4) Creating a project information system. }\end{array}$ \\
\hline 16 & Scenario 16 & $\begin{array}{l}\text { (1) Training; (2) Creating a project information system, and (3) Increase the } \\
\text { number of Engineers. }\end{array}$ \\
\hline
\end{tabular}

The 3 scenarios were selected based on the scenario's ability to reduce the percentage of the number of reworks if it was carried out for the next 1 year or the next project, this scenario was the improvement scenario 13 which was the scenario to reduce the percentage of the number of reworks with the most significant value of $23.11 \%$. The improvement scenario 9 is also able to reduce the percentage of the number of reworks by $22.95 \%$ but more repairs are being made. The implementation of the improvement scenario is a combination of the results obtained to reduce the rework and the costs that need to be spent in carrying out the corrective steps. 
Table 3. The scenario was chosen to minimize the rework

\begin{tabular}{lcl}
\hline Alternative & Perform & Implements \\
\hline Pessimistic & $\mathbf{1 . 7 6 \%}$ & Adding a topographic measurement corridor due to changes in alignment. \\
\hline Moderate & $\mathbf{6 . 2 0 \%}$ & $\begin{array}{l}\text { (1) Training; (2) Creating an Information System project for integration; } \\
\text { and (3) Increase engineer. }\end{array}$ \\
\hline Optimistic & $\mathbf{2 3 . 1 1 \%}$ & $\begin{array}{l}\text { (1) Adding a geotechnical investigation point, so that the accuracy of } \\
\text { boring results does not differ from field conditions; and (2) Increase the } \\
\text { number of supervisors, so that the construction implementation is } \\
\text { following the required method, and quality control can be maintained. }\end{array}$
\end{tabular}

\section{CONCLUSION}

The factors that must be considered are the company's experience in doing similar work, which is the factor that has the highest index value, namely:

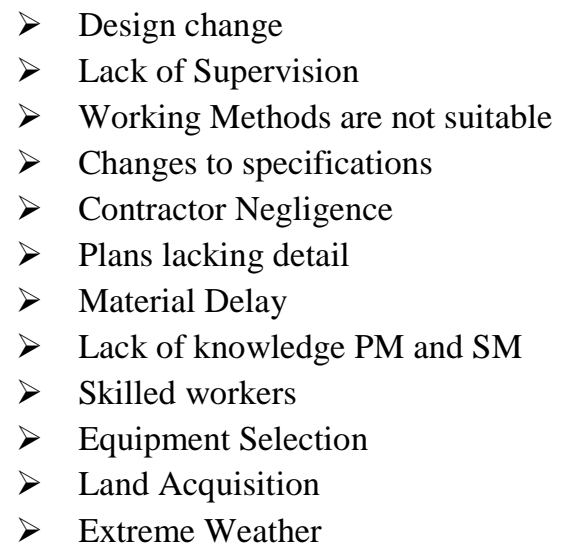

Result of Implementation of System Dynamic to Improve Cost Performance on Toll Road Projects: The budget for the construction costs is IDR 2,296,818,088,784, Rework cost budget of $12.37 \%$ or IDR 284,119,416,006

- Minimum Scenario (Pessimistic) 1.76\% x IDR 284,119,416,006 = IDR 5,000,501,721

- Intermediate Scenario (Moderate) 6.20\% x IDR 284,119,416,006 = IDR 17,615,403,792

- $\quad$ Maximum Scenario (Optimistic)23.11\% x IDR 284,119,416,006 = IDR 65,659,997,039

\section{REFERENCES}

1. Husin, A. E., Berawi, M. A., Dikun, S., Ilyas, T., \& Berawi, A. R. B. (2015). Forecasting demand on mega infrastructure projects: Increasing financial feasibility. International Journal of Technology, 6(1), 73-83. https://doi.org/10.14716/ijtech.v6i1.782

2. Anastasopoulos, P. C., Labi, S., Bhargava, A., \& Mannering, F. L. (2012). An empirical assessment of the likelihood and duration of highway project time delays. Journal of Construction Engineering and Management, 138(3), 390-398. https://doi.org/10.1061/(ASCE)CO.1943-7862.0000437 
3. Berawi, M. A., Zagloel, T. Y. M., Berawi, A. R. B., \& Abdurachman, Y. (2015). Feasibility analysis of trans-Sumatera toll road using value engineering method. International Journal of Technology, 6(3), 388-399. https://doi.org/10.14716/ijtech.v6i3.1475

4. Hwang, B.-G., Thomas, S. R., Asce, M., Carl, ; Haas, T., \& Caldas, C. H. (n.d.). Measuring the Impact of Rework on Construction Cost Performance. https://doi.org/10.1061/ASCE0733-93642009135:3187

5. Barber, P., Graves, A., Hall, M., Sheath, D., \& Tomkins, C. (2000). Quality failure costs in civil engineering projects. International Journal of Quality and Reliability Management. https://doi.org/10.1108/02656710010298544

6. Love, Peter E.D., Sing, C. P., Wang, X., Irani, Z., \& Thwala, D. W. (2014). Overruns in transportation infrastructure projects. Structure and Infrastructure Engineering. https://doi.org/10.1080/15732479.2012.715173

7. Burati, Farrington, J. J., \& Ledbetter, W. B. (1992). Causes o f quality deviations in design and construction. 118(1), 34-49.

8. Love, Peter E.D., \& Sohal, A. S. (2003). Capturing rework costs in projects. Managerial Auditing Journal. https://doi.org/10.1108/02686900310474343

9. Kumaraswamy, M. M., \& Chan, D. W. M. (1998). Contributors to construction delays. Construction Management and Economics. https://doi.org/10.1080/014461998372556

10. Love, Peter E.D. (2002). Influence of project type and procurement method on rework costs in building construction projects. Journal of Construction Engineering and Management. https://doi.org/10.1061/(ASCE)0733-9364(2002)128:1(18)

11. Kaming, P. F., Olomolaiye, P. O., Holt, G. D., \& Harris, F. C. (1997). Factors influencing construction time and cost overruns on high-rise projects in Indonesia. Construction Management and Economics. https://doi.org/10.1080/014461997373132

12. Alessandri, T. M., Ford, D. N., Lander, D. M., Leggio, K. B., \& Taylor, M. (2004). Managing risk and uncertainty in complex capital projects. Quarterly Review of Economics and Finance.

13. Love, P., \& Smith, J. (2018). Unpacking the ambiguity of rework in construction: making sense of the literature. In Civil Engineering and Environmental Systems. https://doi.org/10.1080/10286608.2019.1577396

14. Maseko, C. M. (2018). IDENTIFICATION OF RISK FACTORS AFFECTING CONSTRUCTION OF PROJECTS: THE CASE OF EMERGING ECONOMY. Risk Governance and Control: Financial Markets and Institutions. https://doi.org/10.22495/rgc7i4c2art7

15. Sterman, J. (2000). Business Dynamics, System Thinking and Modeling for a Complex World. Http://Lst-Iiep.IiepUnesco.Org/Cgi-Bin/Wwwi32.Exe/[In=epidoc1.in]/?T2000=013598/(100), 19. 